\title{
HUBUNGAN ANTARA KEBERADAAN DURI DENGAN TOKSISITAS KARANG LUNAK DAN SPONGE
}

\begin{abstract}
Muhammad Nursid, Thamrin Wikanta, Hedi Indra Januar dan Nurrahmi Dewi Fajarningsih" ABSTRAK

Penelitian yang bertujuan untuk mengetahui hubungan antara keberadaan duri dengan toksisitas ekstrak metanol karang lunak dan sponge telah dilakukan. Sebanyak 28 jenis ekstrak karang lunak dan sponge diuji toksisitasnya menggunakan uji Brine Shrimp Lethality Test (BSLT). Perbedaan mortalitas Artemia salina akibat pemberian ekstrak diuji dengan uji $t$ dua sampel independen. Korelasi antara keberadaan duri dengan tingkat toksisitas dianalisis dengan korelasi nonparametrik Spearman. Hasil penelitian menunjukkan bahwa ekstrak dari sampel yang berduri memiliki tingkat toksisitas yang lebih rendah dibandingkan dengan sampel yang tidak berduri. Tingginya tingkat toksisitas pada sampel yang tidak berduri berkaitan dengan keberadaan senyawa metabolit sekunder yang diduga secara ekologis berfungsi sebagai alat pertahanan diri secara kimia. Analisis korelasi Spearman menunjukkan bahwa terdapat hubungan yang nyata antara keberadan duri dengan tingkat toksisitas.
\end{abstract}

\begin{abstract}
Relationship between the occurrence of thorn and toxicity of soft coral and sponges. By: Muhammad Nursid, Thamrin Wikanta, Hedi Indra Januar and Nurrahmi Dewi Fajarningsih

A research to find out the relationship between the occurrence of thorn on soft coral and sponges with the toxicity of their methanol extract has been carried out. The toxicity levels of 28 samples of soft coral and sponges were tested using Brine Shrimp Lethality Test (BSLT) method. The mortality of Artemia salina due to addition of sample extract was statistically analyzed using independent samples $t$ test. Correlation between the occurrence of thom and toxicity level was tested using the Spearman non parametric correlation test. The result showed that the toxicity level of thorny samples was lower than that of non thorny samples. Non thorny samples (lacking defense structure) had a high toxicity level. Non thorny samples posses secondary metabolite which possibly perform as a chemical defense. Spearman correlation analysis showed a significant correlation between the occurrence of thom and the toxicity level.
\end{abstract}

KEYWORDS: chemical defense, toxicity, sponges and soft coral

\section{PENDAHULUAN}

Selama ini eksplorasi senyawa metabolit sekunder yang berasal dari ekosistem lautan sudah banyak dilakukan, terutama untuk tujuan farmakologis. Invertebrata (terutama sponge dan koral) dikenal memiliki senyawa metabolit sekunder yang potensial sebagai antibiotik, antitumor, antiviral dan antiinflamasi (Faulkner, 2000; Jha \& Zi-rong, 2004). Namun demikian, studi mengenai peran ekologis senyawa metabolit sekunder masih jarang dilakukan dibanding dengan studi senyawa metabolit sekunder untuk tujuan farmakologis (Pawlik et al., 2002).

Interaksi antar organisme di dalam laut khususnya pada ekosistem terumbu karang berjalan kompleks.
Semua anggota komunitas berusaha untuk tetap bertahan hidup dengan memanfaatkan sumberdaya yang tersedia sesuai dengan relung ekologis (ecological niche) masing-masing. Ekosistem terumbu karang merupakan ekosistem yang memiliki keanekaragaman jenis yang tinggi. Kubanek et al. (2002) dan Henkel \& Pawlik (2005) menyatakan bahwa ekosistem terumbu karang ditandai dengan tingginya tingkat pemangsaan dan kompetisi spasial antar anggota komunitas karena terbatasnya ruang.

Metabolit sekunder memainkan peranan yang penting sebagai pembawa "pesan kimia" baik di lingkungan terestrial maupun lingkungan lautan, terutama berperan dalam mengatur interaksi organisme yang bersifat sesil dan memiliki pergerakan

-) Peneliti pada Balai Besar Riset Pengolahan Produk dan Bioteknologi Kelautan dan Perikanan 
yang sangat lambat (Fontana et al., 2001). Senyawa metabolit sekunder yang dihasilkan berguna sebagai sarana mempertahankan diri dari serangan predator, kompetitor, dan organisme patogen (Pawlik 1993; Puyana et al., 2003).

Menurut Jones et al. (2005), mekanisme pertahanan diri pada tumbuhan dalam lingkungan terestrial untuk menghindari predasi dari hewan herbivor dilakukan dengan sistem pertahanan fisik seperti duri yang tajam dan keras atau melalui sistem pertahanan kimia misalnya dengan mengeluarkan zat alelopati sebagai respon ekologis untuk tetap bertahan hidup dalam rangka mengurangi resiko pemangsaan. Sama halnya dengan strategi pertahanan diri pada tumbuhan terestrial, organisme yang bersifat bentiksesil dalam lingkungan laut menggunakan sistem pertahanan diri secara kimia dengan memproduksi senyawa metabolit sekunder dan secara fisik misalnya dengan membentuk spikula pada sponge (Jones et al., 2005).

Hasil pengambilan sampel sponge dan karang lunak yang telah dilakukan pada ekosistem terumbu karang di Kepulauan Seribu dan Kepulauan Karimunjawa memperlihatkan bahwa di antara sampel tersebut banyak yang memiliki struktur tubuh luar yang keras (berduri dan kasar) dan yang lembut atau halus. Berdasarkan bentuk luar sampel yang diamati, secara umum sampel dapat dibagi menjadi dua kelompok besar yaitu sampel yang berduri dan sampel yang memiliki tubuh luar lunak. Penelitian ini bertujuan untuk mengetahui hubungan antara keberadaan duri (termasuk sampel yang bertubuh keras) dengan tingkat toksisitas terhadap larva Artemia salina.

\section{BAHAN DAN METODE}

\section{Pengambilan Sampel dan Identifikasi}

Sampel diambil dari Perairan Karimunjawa dan Kepulauan Seribu masing-masing pada bulan $\mathrm{Mei}$ 2005 dan Juni 2005. Sampel yang diperolah pada kedalaman 5-15 meter dengan Scuba Diving ditimbang lalu diawetkan menggunakan larutan metanol teknis. Identifikasi dilakukan menurut Colin \& Arneson (1995), Manuputty (2002), Alderslade (2003) dan Benayahu et al. (2004). Identifikasi spesimen dilaksanakan sampai ke takson yang paling memungkinkan.

Sampel dikelompokkan menjadi dua kelompok yaitu sampel yang berduri dan tidak berduri. Sampel berduri dicirikan oleh adanya duri di permukaan tubuh sampel, sedangkan sampel yang tidak berduri dicirikan oleh tidak adanya duri di permukaan tubuh dan tekstur permukaan yang lunak

\section{Ekstraksi}

Ekstraksi dilakukan dengan menggunakan pelarut metanol teknis. Sebanyak $100 \mathrm{~g}$ sampel dipotongpotong lalu dimasukkan ke dalam larutan metanol teknis dan dimaserasi selama 24 jam. Proses maserasi ini dilakukan sebanyak 3 kali. Larutan yang diperoleh digabung dan dievaporasi dengan Buchi Rotavapor pada suhu water bath $27^{\circ} \mathrm{C}$ dan suhu kondensor $2^{\circ} \mathrm{C}$. Evaporasi dilakukan sampai pelarut kering, sisa air yang masih terdapat pada ekstrak dikeringkan dengan pengering beku (freeze dryer) pada suhu $-43^{\circ} \mathrm{C}$ sampai diperoleh ekstrak kasar (crude extract) berbentuk bubuk.

\section{Uji Toksisitas}

Uji toksisitas dilakukan dengan menggunakan metode Brine Shrimp Lethality Test (BSLT) menurut metode McLaughlin \& Rogers (1998). Uji toksisitas dilakukan terhadap 28 jenis biota yang meliputi 14 jenis biota berduri atau memiliki struktur tubuh bagian luar yang keras dan 14 jenis biota tidak berduri dengan srtuktur tubuh luar yang lunak dan berdaging.

Hewan uji yang digunakan adalah larva Artemia salina. Kista $A$. salina ditetaskan di dalam air laut buatan ( $38 \mathrm{~g}$ garam dapur dalam $1 \mathrm{~L}$ air biasa) dan ditempatkan di bawah lampu TL 40 watt. Setelah 48 jam kista menetas manjadi nauplii instar III/IV dan siap digunakan sebagai hewan uji. Sepuluh larva $A$. salina dimasukkan ke dalam vial yang telah berisi ekstrak sampel dengan dosis 10, 100 dan 1000 ppm (masing-masing dosis terdiri dari 3 vial sehingga jumlah A. salina yang diuji tiap dosis berjumlah 30 ekor) kemudian ditambahkan air laut buatan sampai volume $10 \mathrm{ml}$. Air laut buatan tanpa pemberian ekstrak (0 ppm) digunakan sebagai kontrol. Semua vial diinkubasi pada suhu kamar selama 24 jam di bawah penerangan lampu $T L 40$ watt. Pengamatan dilakukan setelah 24 jam dengan menghitung jumlah $A$. salina yang mati pada tiap perlakuan.

\section{Analisis Data}

Untuk melihat perbedaan antara jumlah A. salina yang mati pada larutan ekstrak yang berasal dari sampel yang berduri dengan larutan ekstrak yang berasal dari contoh yang tidak berduri dilakukan uji t dua sampel independen. Korelasi antara sampel berduri atau tidak berduri dengan tingkat toksisitas dianalisis dengan korelasi nonparametrik Spearman. Prosedur uji t dan korelasi Spearman dilakukan menurut Santoso (2000). 


\section{HASIL DAN BAHASAN}

Sampel berduri yang berhasil dikoleksi dan diuji toksisitasnya sebagian besar terdiri dari genus Dendronephthya (karang lunak), sisanya terdiri dari genus Callyspongia (sponge) dan 1 jenis yang tidak teridentifikasi dari familia Niphatidae (sponges). Sampel biota yang tidak berduri sebagian besar termasuk dalam genus Sarcophyton, sisanya terdiri dari genus Sinularia, Lobophytum dan 3 jenis karang gorgonia. Beberapa contoh foto sampel yang memperlihatkan sampel berduri dan tidak berduri disajikan pada Gambar 1. Deskripsi morfologi terhadap sampel berduri dan tidak berduri disajikan pada Tabel 1 dan 2.

Karang lunak dari genus Dendronephthya yang diuji toksisitasnya dalam penelitian ini memiliki warna sangat menarik (Gambar 1 Adan B) tetapi mempunyai banyak duri tajam. Hal yang sama dapat dilihat pada sponge Callyspongia (Gambar $1 \mathrm{C}$ ) yang memiliki duriduri yang tajam di sepanjang tubuhnya. Duri-duri yang

Tabel 1. Deskripsi morfologi spesimen berduri

Table 1. Morphology description of thomy specimen

\section{No Spesimen/Specimen}

1 Dendronephthya 1

2 Dendronephthya 2

3 Dendronephthya 3

4 Dendronephthya 4

5 Dendronephthya 5

6 Dendronephthya 6

7 Dendronephthya 7

8 Dendronephthya 8

9 Dendronephthya 9

10 Dendronephthya 10

\section{Deskripsi morfologi/Morphology description} Karang lunak, warna duri merah tua, warna tubuh kuning muda, percabangan pendek, berlendir/Soft coral, dark red thom, light yellow body, short branching, slimy

Karang lunak, warna duri kuning, duri mirip bunga kembang sepatu, warna tubuh kuning muda, percabangan pendek, berlendir/Soft coral, yellow thom, thom resembles hibiscus flowers, light yellow body, short branching, slimy

Karang lunak, warna duri merah, warna tubuh kuning, percabangan pendek, berlendir/Soft coral, red colour thom, yellow colour body, short branching, slimy

Karang lunak, warna duri coklat, warna tubuh putih, percabangan pendek, berlendir/Soft coral, brown colour thorn, white colour body, short branching, slimy

Karang lunak, warna duri kuning, duri mirip bunga kembang sepatu, warna tubuh kuning muda, percabangan pendek, berlendir/Soft coral, yellow thron, thom resembles hibiscus flowers, light yellow body, short branching, slimy

Karang lunak, warna duri kuning pucat, warna tubuh kuning, percabangan, berlendir/Soft coral, light yellow colour thorn, yellow colour body, branching, slimy

Karang lunak, warna duri coklat kekuningan, duri lebih sedikit, warna tubuh putih, percabangan panjang/Soft coral, with a few yellowish brown colour thom, white colour body, long branching

Karang lunak, warna duri oranye, warna tubuh kuning, percabangan pendek, berlendir/Soft coral, orange colour, yellow colour body, short branching, slimy

Karang lunak, warna duri oranye dan bergerombol, warna tubuh oranye, percabangan pendek dan berjumlah sedikit/Soft coral, orange gathered thorn, orange body, with a few short branching

Karang lunak, warna duri oranye, warna tubuh oranye, percabangan pendek, berlendir/Soft coral, orange colour thom, short branching, slimy 
Tabel 1. Deskripsi morfologi spesimen berduri (lanjutan)

Table 1. Morphology description of thorny specimen (continued)

\begin{tabular}{ccc}
\hline No & Spesimen/Specimen & \multicolumn{1}{c}{ Deskripsi morfologi/Morphology description } \\
\hline 11 Callyspongia 1 & $\begin{array}{l}\text { Sponge, berduri, warna tubuh dan duri abu-abu, bentuk tubuh } \\
\text { memanjang seperti pipa/Sponge, thorny, grey colour thorn and body, } \\
\text { a long tube body shope } \\
\text { Sponge, berduri panjang, warna tubuh dan duri abu-abu, bentuk } \\
\text { tubuh memanjang seperti pipa/Sponge, grey body with a long grey } \\
\text { thron, a long tube body shape }\end{array}$ \\
12 Callyspongia 2 & $\begin{array}{l}\text { Sponge, berduri panjang, warna tubuh dan duri abu-abu, bentuk } \\
\text { tubuh lebih pendek dan bercabang/Sponge, grey body with a long } \\
\text { grey thorn, short and branching body shape } \\
\text { Sponge, berduri pendek, warna tubuh dan duri merah, bentuk tubuh } \\
\text { memanjang seperti pipa dan bercabang/Sponge, small red thorn, red } \\
\text { long tube branching body shape }\end{array}$ \\
\hline
\end{tabular}

Tabel 2. Deskripsi morfologi spesimen tidak berduri

Table 2. Morphology description of non-thomy specimen

\section{No Spesimen/Specimen Deskripsi morfologi/Morphology description}

\begin{tabular}{|c|c|c|}
\hline 1 & Sarcophyton 1 & $\begin{array}{l}\text { Karang lunak, warna tubuh kuning kecoklatan, bentuk tubuh pipih } \\
\text { berlipat, permukaan tubuh licin dan berbintik, tidak bercabang, } \\
\text { berlendir/Soft coral, brawnish yellow body, thin folded body shape, } \\
\text { smooth, spotted and slimy body surface without branch }\end{array}$ \\
\hline 2 & Sarcophyton 2 & $\begin{array}{l}\text { Karang lunak, warna tubuh kuning kusam, bentuk tubuh mirip } \\
\text { Dendronephthya tetapi tidak berduri, bercabang pendek, } \\
\text { berlendir/Soft coral, dark yellow body, dendronephthya resembles } \\
\text { body shape without thorn, short branching, slimy }\end{array}$ \\
\hline 3 & Sarcophyton 3 & $\begin{array}{l}\text { Karang lunak, warna tubuh kuning kecoklatan, bentuk tubuh pipin } \\
\text { berlipat, permukaan tubuh licin dan berbintik, tidak bercabang, } \\
\text { berlendir/Soft coral, brawnish yellow body, thin folded body shape, } \\
\text { smooth, spotted and slimy body surface without branch }\end{array}$ \\
\hline 4 & Sarcophyton 4 & $\begin{array}{l}\text { Karang lunak, warna tubuh kuning kecoklatan, bentuk tubuh pipih } \\
\text { berlipat, permukaan tubuh licin tidak berbintik, tidak bercabang, } \\
\text { berlendir/Soft coral, brownish yellow body, thin folded body shape, } \\
\text { smooth and slimy, body surface without spot, without bran }\end{array}$ \\
\hline 5 & Sarcophyton 5 & $\begin{array}{l}\text { Karang lunak, warna tubuh abu-abu, bentuk tubuh pipih berlipat, } \\
\text { permukaan tubuh licin dan berbintik, tidak bercabang, berlendir/Soft } \\
\text { coral, grey colour body, thin folded body shape, smooth-spotted } \\
\text { slimy body surface, without branch }\end{array}$ \\
\hline 6 & Sarcophyton 6 & $\begin{array}{l}\text { Karang lunak, warna tubuh kuning kecoklatan, bentuk tubuh pipih } \\
\text { berlipat, permukaan tubuh licin tidak berbintik, tidak bercabang, } \\
\text { berlendir/Soft coral, brownish yellow body, thin folded body shape, } \\
\text { smooth slimy body surface without spot, without branch }\end{array}$ \\
\hline
\end{tabular}


Tabel 2. Deskripsi morfologi spesimen tidak berduri (lanjutan)

Table 2. Morphology description of non-thorny specimen (continued)

\section{No Spesimen/Specimen}

\section{Deskripsi morfologi/Morphology description}

\begin{tabular}{|c|c|c|}
\hline 7 & Sarcophyton 7 & $\begin{array}{l}\text { Karang lunak, warna tubuh abu-abu, bentuk tubuh pipih berlipat, } \\
\text { permukaan tubuh licin dan berbintik, tidak bercabang, berlendir/Soft } \\
\text { coral, grey colour body, thin folded body shape, smooth-spotted } \\
\text { slimy body surface, without branch }\end{array}$ \\
\hline 8 & Sinularia 1 & $\begin{array}{l}\text { Karang lunak, warna tubuh krem, permukaan tubuh berbintil besar, } \\
\text { bentuk tubuh pipih tidak berlipat, tidak bercabang/Soft coral, cream } \\
\text { colour body, body surface with nodule without branch }\end{array}$ \\
\hline 9 & Sinularia 2 & $\begin{array}{l}\text { Karang lunak, warna tubuh krem, permukaan tubuh berbintil tetapi } \\
\text { lebih kecil dari Sinularia 1, bentuk tubuh pipih tidak berlipat, tidak } \\
\text { bercabang/Soft coral, cream colour body, body surface with smaller } \\
\text { nodule than Sinularia } 1 \text {, thin body shape, without branch }\end{array}$ \\
\hline 10 & Sinularia 3 & $\begin{array}{l}\text { Karang lunak, warna tubuh abu-abu, permukaan tubuh berbintil } \\
\text { berbintil dan mengandung bulu-bulu halus, bentuk agak membulat, } \\
\text { tidak bercabang/Soft coral, grey colour body, body surface with } \\
\text { nodule and soft body hair, globular thin body shape, without branch }\end{array}$ \\
\hline 11 & Lobophytum & $\begin{array}{l}\text { Karang lunak, warna tubuh kuning, permukaan tubuh berbintil dan } \\
\text { mengandung bulu-bulu halus, bentuk pipih dan agak membulat, tidak } \\
\text { bercabang/Soft coral, yellow colour body, body surface with nodule } \\
\text { and soft body hair, globular, thin body shape, without branch }\end{array}$ \\
\hline 12 & Astrogorgia & $\begin{array}{l}\text { Karang gorgonia, warna tubuh oranye, percabangan cenderung } \\
\text { melintang/Gorgonian coral, orange colour body, crosswise branching }\end{array}$ \\
\hline 13 & Muricella & $\begin{array}{l}\text { Karang gorgonia, warna tubuh oranye, percabangan cenderung } \\
\text { membujur/Gorgonian coral, orange colour body, longitudinal } \\
\text { branching }\end{array}$ \\
\hline 14 & Subergorgia & $\begin{array}{l}\text { Karang gorgonia, warna tubuh coklat, percabangan cenderung } \\
\text { melintang, permukaan tubuh berbintik-bintik putih/Gorgonian coral, } \\
\text { brown colour body, crosswise branching, body surface with white } \\
\text { nodule }\end{array}$ \\
\hline
\end{tabular}

terdapat pada organisme tersebut secara ekologis berperan untuk melindungi diri dari serangan predator. Sebaliknya karang gorgonia dari genera Muricella (Gambar 1 D), Sarcophyton (Gambar 1 E) dan Lobophytum (Gambar $1 \mathrm{~F}$ ) tidak memiliki pertahanan fisik yang dicirikan oleh jaringan yang bertekstur lembut, lunak dan berdaging.

Hasil uji toksisitas terhadap sampel-sampel tersebut disajikan pada Tabel 3. Jumlah larva A. salina yang mati setelah diberi perlakukan ekstrak kasar metanol dengan dosis 10 ppm menunjukkan perbedaan yang sangat nyata $(p<0,012)$ antara sampel yang berduri dengan yang tidak berduri. Demikian juga dengan dosis 100 ppm dan 1000 ppm jumlah larva $A$. salina yang mati menunjukkan perbedaan yang sangat nyata masing-masing dengan nilai $p<0,001$ dan $p<0,0001$. Rata-rata jumlah $A$. salina yang mati pada kedua jenis sampel dengan karakteristik morfologi yang berbeda tersebut disajikan pada Gambar 2.

Hasil analisis korelasi Spearman ( $r$ ) menunjukkan bahwa terdapat hubungan yang nyata $(p<0,001)$ antara jumlah A.salina yang mati dengan keberadaan duri pada dosis 10, 100 dan 1000 ppm masing-masing dengan nilai $r$ sebesar $-0,557,-0,594$ dan $-0,630$. Hasil ini mengindikasikan adanya hubungan yang kuat antara ketiadaan duri dengan tingkat toksisitas. Ekstrak dari sampel yang berduri memiliki tingkat toksisitas yang lebih rendah dibandingkan dengan ekstrak dari sampel yang tidak berduri dan bertubuh 


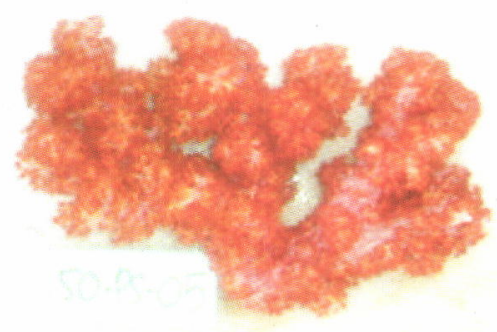

A. Dendronephthya (Kepulauan Seribu)

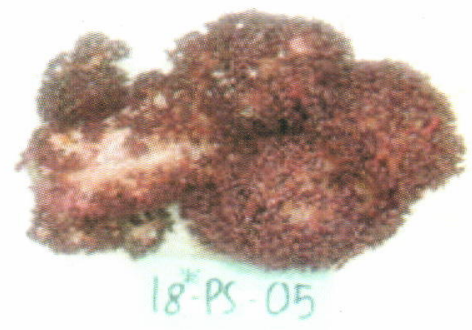

B. Dendronephthya (Kepulauan Seribu)

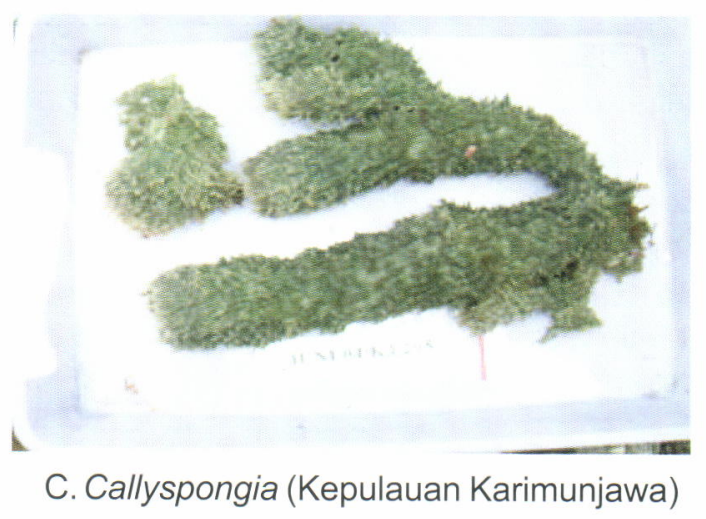

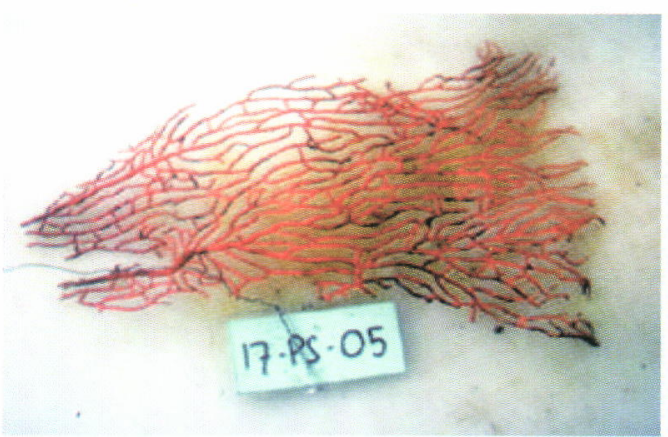

D. Muricella (Kepuiauan Seribu)

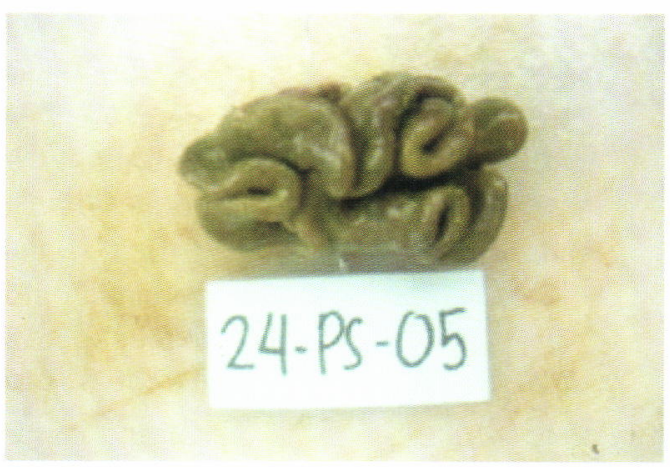

E. Sarcophyton (Kepulauan Seribu)

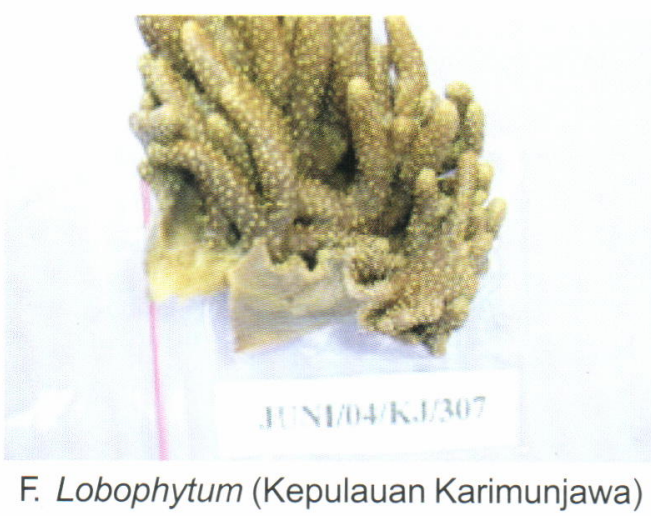

Gambar 1. Foto karang lunak dan sponge yang memiliki tubuh luar berduri (A, B, C) dan yang bertubuh lunak (tidak berduri) ( D, E, F) dari perairan Kepulauan Seribu dan Karimunjawa.

Figure 1. Photos of soft coral and sponges sample that have the thorn $(A, B, C)$ and soft-bodies samples (non thorny) (D, E, F) from Seribu and Karimunjawa Islands.

lunak. Dengan demikian terdapat kecenderungan bahwa karang lunak dan sponge yang tidak berduri memiliki toksisitas lebih tinggi tinggi daripada yang berduri.

Toksisitas yang tinggi berkaitan erat dengan fungsi ekologis dari metabolit sekunder yang dihasilkan. Banyak hewan invertebrata pada ekosistem terumbu karang menggunakan metabolit sekunder sebagai sarana untuk mempertahankan diri secara kimia (Pawlik, 1993). Metabolit sekunder banyak terdapat pada organisme yang mudah dimangsa. Organisme ini mudah dimangsa karena tidak memiliki sarana pertahanan fisik dan bersifatimmobil, seperti sponge, karang lunak, nudibranchia, dan tunikata. Tubuh organisme ini umumnya lunak, berdaging dan kaya dengan protein sehingga menjadi target pemangsaan organisme predator (Burns et al., 2003; Jones et al., 
Tabel 3. Mortalitas Artemia salina pada dosis ekstrak kasar MeOH 10, 100, dan 1000 ppm

Table 3. Mortality of Artemia salina at crude $\mathrm{MeOH}$ l extract doses of 10, 100, and $1000 \mathrm{ppm}$

\begin{tabular}{|c|c|c|c|c|c|c|c|c|c|}
\hline \multicolumn{6}{|c|}{ Sampel Berduri/Thorny samples } & \multicolumn{4}{|c|}{$\begin{array}{c}\text { Sampel Tidak Berduri/Non thorny } \\
\text { samples }\end{array}$} \\
\hline \multirow[t]{2}{*}{ No } & \multirow[t]{2}{*}{ Nama/Name } & \multicolumn{3}{|c|}{$\begin{array}{c}\text { Mortalitas A. salina } \\
\text { (e kor)/M ortality of } A . \\
\text { salina (Ind.) }\end{array}$} & \multirow[t]{2}{*}{ No } & \multirow[t]{2}{*}{ Nama/Name } & \multicolumn{3}{|c|}{$\begin{array}{c}\text { Mortalitas A. salina } \\
\text { (e kor)/Mortality of } A \\
\text { salina (Ind.) }\end{array}$} \\
\hline & & $\begin{array}{c}10 \\
\text { ppm }\end{array}$ & $\begin{array}{r}100 \\
\mathrm{ppm}\end{array}$ & $\begin{array}{l}1000 \\
\text { ppm }\end{array}$ & & & $\begin{array}{c}10 \\
\mathrm{ppm}\end{array}$ & $\begin{array}{r}100 \\
\text { ppm }\end{array}$ & $\begin{array}{l}1000 \\
\mathrm{ppm}\end{array}$ \\
\hline 1 & Dendronephthya $1^{*}$ & 2 & 0 & 8 & 1 & Sarcophyton $1^{*}$ & 6 & 30 & 30 \\
\hline 2 & Dendronephthya $2^{*}$ & 1 & 6 & 6 & 2 & Sarcophyton $2^{*}$ & 3 & 11 & 24 \\
\hline 3 & Dendronephthya $3^{*}$ & 1 & 0 & 9 & 3 & Sarcophyton $3^{*}$ & 3 & 20 & 30 \\
\hline 4 & Dendronephthya $4^{*}$ & 1 & 7 & 7 & 4 & Sarcophyton $4^{*}$ & 12 & 27 & 30 \\
\hline 5 & Dendronephthya $5^{*}$ & 0 & 1 & 1 & 5 & Sarcophyton $5^{\star}$ & 6 & 28 & 30 \\
\hline 6 & Dendronephthya $6^{*}$ & 0 & 2 & 12 & 6 & Sarcophyton $6^{*}$ & 19 & 27 & 30 \\
\hline 7 & Dendronephthya $7^{*}$ & 0 & 11 & 30 & 7 & Sarcophyton $7^{*}$ & 5 & 14 & 29 \\
\hline 8 & Dendronephthya $8^{*}$ & 5 & 5 & 20 & 8 & Sinularia $1^{*}$ & 11 & 17 & 30 \\
\hline 9 & Dendronephthya $9^{*}$ & 5 & 25 & 30 & 9 & Sinularia $2^{*}$ & 1 & 6 & 29 \\
\hline 10 & Dendronephthya $10^{*}$ & 4 & 1 & 3 & 10 & Sinularia $3^{\star}$ & 30 & 29 & 30 \\
\hline 11 & Callyspongia $1^{*}$ & 0 & 1 & 7 & 11 & Lobophytum ** & 3 & 6 & 29 \\
\hline 12 & Callyspongia $2^{*}$ & 0 & 4 & 16 & 12 & Astrogorgia* & 30 & 30 & 30 \\
\hline 13 & Callyspongia $3^{\star *}$ & 4 & 0 & 20 & 13 & Muricella* & 4 & 20 & 24 \\
\hline 14 & Niphatidae* & 0 & 1 & 0 & 14 & Subergorgia* & 0 & 0 & 6 \\
\hline
\end{tabular}

Keterangan/Remarks : * = Sampel dari Kepulauan Seribu/Samples from Seribu Islands,

${ }^{\star \star}$ = Sampel dari Kepulauan Karimunjawa/Samples from Karimunjawa Islands

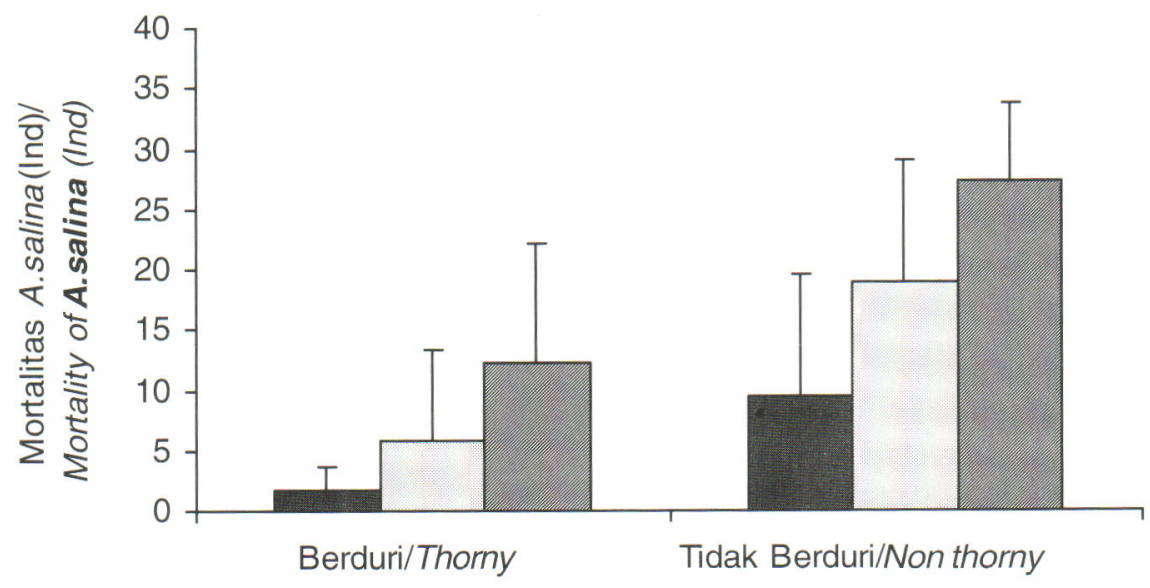

10 ppm $\square 100$ ppm 1000 ppm

Gambar 2. Mortalitas Artemia salina setelah diberi esktrak kasar metanol dari sampel berduri dan tidak berduri pada dosis 10, 100, dan $1000 \mathrm{ppm}$.

Figure 2. Mortality of Artemia salina after addition of methanol crude extract at doses of 10, 100, and 1000 ppm of thorny and non thorny samples. 
2005). Predator yang paling dominan dalam ekosistem terumbu karang adalah ikan, penyu, nudibranchia, dan Echinodermata (Swearingen \& Pawlik, 1998; Jones et al., 2005). Untuk menghindari agar tidak dimangsa oleh predator tersebut maka organisme ini sering memproduksi senyawa kimia yang bersifat toksik. Sebaliknya, organisme yang bersifat mobil seperti ikan atau organisme yang dilindungi oleh cangkang (Crustacea dan Echinodermata), umumnya miskin dengan senyawa metabolit sekunder (Pawlik, 1993)

Interaksi antar organisme dapat berlangsung dengan dua cara yaitu interaksi satu spesies dengan organisme lain dari spesies yang berbeda (interaksi interspesifik) dan interaksi satu spesies dengan organisme lain dari spesies yang sama (interaksi intraspesifik). Menurut Whittaker \& Feeny (1971) dalam Engel \& Pawlik (2000) dalam interaksi ini suatu organisme sering mengeluarkan suatu substansi kimia yang disebut zat allelopati yang diproduksi oleh suatu organisme untuk mempengaruhi pertumbuhan, perilaku, kesehatan, dan populasi organisme lain.

Pawlik (1993) menyatakan bahwa dalam ekosistem terumbu karang, zat allelopati yang dikeluarkan salah satunya dimaksudkan untuk mencegah organisme lain masuk atau menempel ke dalam suatu koloni organisme. Interaksi antara sponges dengan karang keras (Scleractinia) serta antara karang lunak dengan karang Scleractinia terjadi secara kompetitif. Dalam interaksi ini organismeorganisme tersebut mengeluarkan eksudat berupa senyawa metabolit sekunder yang dapat menyebabkan jaringan kompetitor terdekat menjadi rusak (necrosis).

Berbeda dengan karang Scleractinia, karang lunak dari kelas Anthozoa (Gorgonacea dan Alcyonacea) memiliki jaringan tubuh yang lembut dan berdaging sehingga secara fisik tidak memadai sebagai sarana pertahanan diri. Contohnya adalah karang lunak dari genus Lobophytum, Sinularia, atau Sarcophyton serta jenis-jenis karang gorgonian. Untuk mempertahankan kehidupannya, biasanya organisme-organisme ini memiliki sarana pertahanan kimia sebagai pengganti sarana pertahanan fisik.

Contoh peranan pertahanan kimia pada karang lunak dapat dilihat pada salah satu jenis gorgonian Erythropodium caribaeorum. Dalam percobaan laboratorium yang dilakukan oleh Pawlik (1993), pelet yang dicampur dengan ekstrak kasar $E$. caribaeorum dapat mencegah ikan karang memakan pelet yang diberikan. Hal ini disebabkan ekstrak yang diberikan bersifat toksik dan berbau tidak sedap. Sementara itu senyawa pseudopterolide yang berasal dari gorgonian Pseudopterogorgia acerosa dapat berfungsi sebagai defensive-metabolite untuk mencegah pemangsaan oleh ikan predator demikian juga ekstrak kasar dari Sinularia maxima, $S$. polydactyla dan Sinularia sp. (Pawlik, 1993). Contoh metabolit sekunder pada sponge yang secara ekologi berfungsi sebagai sarana untuk mempertahankan diri dari serangan ikan predator adalah senyawa alkoloid, brominated pyrrole, yang terdapat pada sponge Agelas conifera (Assmann et al., 2000).

Mekanisme pertahanan kimia pada sponge tampaknya lebih berperan dari pada mekanisme pertahanan fisik dalam rangka mempertahan hidup (Burns et al., 2003). Hal yang sama dapat dilihat pada Ascidian, yaitu mekanisme pertahanan kimia berperan sangat penting dalam rangka mempertahankan diri (Pisut \& Pawlik, 2002).

Nybakken (1988) serta Colin \& Arneson (1995) menyatakan bahwa sarana pertahanan kimia pada Cnidaria terdapat pada organ penyengat yang disebut nematokis. Nematokis selain berfungsi sebagai sarana perlindungan diri juga digunakan sebagai alat untuk menangkap makanan berupa zooplankton dan juga digunakan sebagai alat untuk melekatkan diri pada substrat. Nematokis karang lunak biasanya segera mengeluarkan lendir beracun apabila koloninya diserang. Misalnya pada Cespitularia sp., bila disentuh meskipun secara hati-hati, menghasilkan banyak lendir yang bersifat mematikan bagi sejumlah krustasea laut yang kecil. Lendir tersebut mengandung terpena toksik palustrol dalam jumlah yang cukup besar. Banyak Cnidaria yang dapat dilindungi secara efektif oleh terpenoid tersebut pada kadar di bawah $0,001 \%$ (Tursch et al., 1995).

Menurut Kerr (2003) dalam Widjhati et al. (2004), sebagai binatang invertebrata yang tidak dapat berpindah, sponges harus mempertahankan diri dari predator maupun persaingan antara untuk mempertahankan wilayah pertumbuhannya. Sponge berkembang biak secara aseksual dan seksual. Cara aseksual yaitu pertumbuhan melalui pembentukan tonjolan tunas (budding) atau memperluas lapisanlapisan tubuhnya dengan jaringan otot. Apabila dua spesies sponge dalam pertumbuhannya saling bertemu maka hanya ada dua kemungkinan, melapisi atau dilapisi. Yang dilapisi akan kalah dan mati. Untuk itu mereka bersaing membuat senjata yang paling beracun untuk bertahan hidup. Senjata beracun yang berbentuk metabolit sekunder tersebut dirancang untuk melawan pertumbuhan sel-sel koloni lain yang cepat.

Sumber senyawa aktif pada sponge sampai saat ini masih menjadi bahan penelitian. Pertanyaan apakah senyawa aktif yang dihasilkan berasal dari tubuh sponge itu sendiri atau berasal dari organisme lain yang bersimbion dengan sponge belum terjawab 
dengan tuntas. Faulkner et al. (1994) dan Proksch et al. (2003) menyatakan bahwa senyawa aktif yang dihasilkan sponge sebenarnya berasal dari mikroorganisme simbiotik yang hidup pada tubuh sponge. Penelitian terus dilakukan untuk membuktikan bahwa mikroorganisme simbiotik merupakan produser senyawa aktif pada sponge. Kuramoto et al. (2004) menyatakan bahwa senyawa metabolit sekunder yang berasal dari lingkungan laut banyak memiliki struktur yang mirip dengan senyawa metabolit sekunder yang ada di lingkungan terestrial. Misalnya senyawa aburatubolactams yang berasal dari invertebrata laut secara biogenetik sangat mirip dengan ikarugamycin yang diproduksi oleh Actinomycetes yang hidup di lingkungan terestrial. Hal ini menguatkan dugaan bahwa mikroorganisme merupakan produser bagi sebagian besar metabolit sekunder yang berasal dari lingkungan laut. Menurut Widjhati et al., (2004), dengan teknik sekuensing gen, diketahui bahwa mikroorganisme simbiotik yang hidup pada sponge terutama berasal dari keluarga Actinomycetes.

Bahan metabolit sekunder yang memiliki peran ekologis yang penting ini menurut Pawlik (1993) sebenarnya merupakan hasil sampingan dari kegiatan metabolisme harian sponge. Belum diketahui dengan pasti pengaruh lingkungan abiotik terhadap jumlah dan jenis metabolit sekunder yang dihasilkan termasuk pengaruh keberadaan mikroba pada sponge terhadap toksisitas bahan metabolit sekunder. Tidak menutup kemungkinan bahwa toksisitas bahan metabolit sekunder yang dihasilkan berhubungan dengan jumlah mikroba yang ada pada tubuh sponge maupun' karang lunak.

\section{KESIMPULAN DAN SARAN}

Berdasarkan penelitian yang sudah dilakukan dapat disimpulkan bahwa terdapat hubungan yang nyata antara keberadaan duri dengan tingkat toksisitas yang dihasilkan. Sponge dan karang lunak yang tidak memiliki duri cenderung memiliki toksisitas yang lebih tinggi daripada karang lunak yang memiliki duri pada bagian luar tubuhnya. Meskipun demikian, penelitian lanjutan perlu dilakukan dengan menggunakan jumlah sampel yang lebih besar dari jenis dan lokasi yang lebih beragam sehingga hubungan antara toksisitas metabolit sekunder dengan keberadaan duri sebagai sarana mempertahankan diri secara fisik dapat tergambar dengan lebih jelas.

\section{DAFTAR PUSTAKA}

Alderslade, P. 2003. A new genus and new species of soft coral (Octocorallia : Alyconacea : Alyconiidae) from the South Western Region of Australia. Zootaxa, 175: $1-10$
Assmann, M., Lichte, E., Pawlik, J.R., Kock, M. 2000. Chemical defense of the Caribbean sponges Agelas wiedenmayeri and Agelas conifera. Marine Ecology Progress Series, 207: 255-262.

Benayahu, Y, Ming-Shiou, J., Perkol-Finkel, S. and FengChang, D. 2004. Soft coral (Octocorallia : Alyconacea) from Southern Taiwan II. Species diversity and distributional patterns. Zoological Studies, 43(3): 548560.

Burns, E., Ifrach, I., Carmeli, S., Pawlik, J.R. and llan, M. 2003. Comparison of anti-predatory defenses of Red Sea and Caribbean sponges. I. Chemical defense. Marine Ecology Progress Series, 252: 105-114.

Colin, P.L. and Arneson, C. 1995. Tropical pacific invertebrates. A field guide to the marine invertebrates occurring on tropical pacific coral reefs, seagrass beds and mangrove. Coral Reef Press, California. 296 pp.

Engel, S. and Pawlik, J.R. 2000. Allelopathic activities of sponges extracts. Marine Ecology Progress Series, 207: 273-281

Faulkner, D.J., Unson, M.D., and Bewley, C.A. 1994. The chemistry of some sponges and their symbionts. Pure \& Appl. Chem., 66: 1883-1990.

Faulkner, D.J. 2000. Marine natural products. Nat. Prod. Rep., 17: 7-55.

Fontana, A., Ciavata, M.L., D'Souza, L., Mollo, E., Naik, C.G., Parameswaran, P.S., Wahidulla, S. and Cimino, G. 2001. Selected chemo-ecological studied of marine opisthobranchs from Indian coast. $J$. Indian Inst. Sci., 81: 403-415.

Henkel, T.P. and Pawlik, J.R. 2005. Habitat use by sponge-dwelling brittlestars. Research article. Marine Biology, 146: 301-313.

Jha, R.K. and Zi-rong, X. 2004. Biomedical compounds from marine organism. Marine Drugs, 2: 123-146.

Jones, A.C., Blum, J.E. and Pawlik, J.R. 2005. Testing for defensive synergy in Caribbean sponges: bad taste or glass spicules? J. Exp. Mar. Biol. and Ecology, 322: 67-81.

Kubanek, J., Whalen, K.E., Engel, S., Kelly, S.R., Henkel, T.P., Fenical, W., and Pawlik, J.R. 2002. Multiple defensive roles for triterpen glycosides from two Caribbean sponges. Oecologia, 131: 125-136.

Kuramoto, M., Arimoto, H., and Uemura, D. 2004. Bioactive alkaloids from the sea : A review. Marine Drugs, 1 : 39-54.

Manuputty, A.E.W. 2002. Karang Lunak (Soft Coral) Perairan Indonesia. Bukul, Laut Jawa \& Selat Sunda. Proyek Pemanfaatan dan Diseminasi IPTEK Kelautan. Pusat Penelitian Oseanografi LIPI, Jakarta.

McLaughlin, J.L. and Rogers, L.L. 1998. The use of biological assay to evaluate botanicals. Drug Information Journal, 32: 513-524.

Nybakken, J.W. 1988. Biologi Laut, Suatu Pendekatan Ekologis. Penerjemah : Eidman E., Koesoebiono, Bengen, D.G., Hutomo, M., dan Sukardjo, S. PT. Gramedia, Jakarta.

Pawlik, J.R. 1993. Marine Invertebrate chemical defenses. Chem. Rev, 93: 1911-1922. 
Pawlik, J.R., McFall, G., and Zea, S. 2002. Does the odor from sponges of the genus Ircinia protect them from fish predator? J. Chem. Ecology, 28(6): 11031115

Pisut, D.P. and Pawlik, J.R. 2002. Anti-predatory chemical defenses of asciadians: secondary metabolits or inorganic acid? J. Exp. Mar. Biol. and Ecology, 270: 203-214.

Proksch, P., Edrada, R.A., and Ebel R. 2003. Drugs from the sea-current status and microbial implications. Appl. Microbiol. Biotechnol, 59: 125-134.

Puyana, M., Fenical, W., and Pawlik, J.R. 2003. Are the activated chemical defenses in sponge of the genus Aplysina from the Caribbean? Marine Ecology Progress, 246: 127-135.

Swearingen, D.C. and Pawlik, J.R. 1998. Variability in the chemical defense of the sponge Chondrilla nucula against predatory reef fishes. Marine Biology, 131: 619-627.

Santoso, S. 2000. SPSS Mengolah Data Secara Profesional. PT. Elex Media Komputindo, Jakarta.

Tursch, B., Braekman, J.C. Daloze, D. and Kaisin, M. 1995. Terpenoid dari Coelenterata. Dalam : Produk Alami Lautan dari Segi Kimia dan Biologi. Jilid II. In : Scheurer, P.J. (ed.). Penerjemah : Koensoemardiyah. IKIP Semarang Press, Semarang. 387 pp.

Widjhati, R., Supriyono, A. dan Subintoro. 2004 Pengembangan Senyawa Bioaktif dari Biota Laut. Makalah pada Forum Bioteknologi Kelautan dan Perikanan, Pusat Riset Pengolahan Produk dan Sosial Ekonomi Kelautan dan Perikanan, Depertemen Kelautan dan Perikanan. Tanggal 25 Maret 2004. 13 pp. 